\title{
Genetic structure of Neisseria gonorrhoeae populations: a non-clonal pathogen
}

\author{
MARIA O'RourKE* and Evelyn STEVENS
}

Department of Microbiology, University College Galway, Galway, Ireland

(Received 7 June 1993; revised 22 July 1993; accepted 23 July 1993)

\begin{abstract}
Reproduction by binary fission generates a clonal genetic structure in bacterial populations in the absence of a high rate of recombination. The extent of recombination in natural populations of Neisseria gonorrhoeae was determined from an analysis of electrophoretically demonstrable allelic variation at structural genes encoding nine enzyme loci in 227 worldwide isolates. No significant linkage disequilibrium was evident in the population, indicating that recombination must be frequent, relative to binary fission. The genetic structure of $N$. gonorrhoeae was compared with that of Bacillus subtilis from an earlier study. Linkage disequilibrium was less extreme in the $N$. gonorrhoeae population than in the local population of $B$. subtilis, in which only modest clonal structure was evident. Thus, $N$. gonorrhoeae, unlike pathogens so far examined, has a non-clonal population structure. As expected in a freely recombining population, no correlation was found between electrophoretic genotype and serovar or auxotype.
\end{abstract}

\section{Introduction}

Neisseria gonorrhoeae is the causative agent of gonorrhoea, a disease which has been recognized since antiquity and is still a common bacterial infection (Centers for Disease Control, 1992). Auxotyping and serovar determination have been accepted as the two major phenotypic systems for the typing of $N$. gonorrhoeae and the combination of both techniques has enabled temporal and geographic changes in gonococcal populations to be monitored (Sarafian \& Knapp, 1989). Information on genetic variation in $N$. gonorrhoeae has been determined from restriction endonuclease analysis (Falk et al., 1984; Poh et al., 1989) and more recently from RFLP analysis using rRNA probes (Poh et al., 1992), while several studies have documented both phase and antigenic variation in gonococcal surface antigens (Seifert \& So, 1988). Although most of these methods have revealed extensive variation in $N$. gonorrhoeae, none has yielded reliable estimates of the extent of variation in the genome as a whole.

The technique of multilocus enzyme electrophoresis

*Author for correspondence. Present address: Microbial Genetics Group, School of Biological Sciences, University of Sussex, Falmer, Brighton BN1 9QG, UK. Fax. +44 273678 433; e-mail: Bafg2@uk.ac.sussex.central.

Abbreviations: ET, electrophoretic type; MLEE, multilocus enzyme electrophoresis; RFLP, restriction fragment length polymorphism.
(MLEE), which indexes allelic variation in multiple chromosomal genes, has been used extensively to determine the genetic structure of natural populations. Such electrophoretic studies have suggested that the population structures of many species, including Escherichia coli (Selander \& Levin, 1980; Selander et al., 1987), Legionella pneumophila (Selander et al., 1985), Listeria monocytogenes (Piffaretti et al., 1989), Haemophilus influenzae (Musser et al., 1988), Serratia marcesens (Gargallo-Viola, 1989) and Bordetella bronchiseptica (Musser et al., 1987) are basically clonal. Clonal structure is characterized by the existence of strong linkage disequilibrium (non-random association of alleles), indicating restricted recombination among alleles at different loci (Selander \& Musser, 1990). As a consequence of infrequent recombination and periodic selection, only a fraction of all possible genotypes are detected and isolates of identical multilocus genotype are recovered from diverse geographic areas over long periods of time.

Although bacterial reproduction is asexual, the transfer of chromosomal genes can be achieved through the processes of transduction, conjugation and transformation. Among those species which exhibit strong linkage disequilibrium, many possess the ability to exchange genetic material by these parasexual methods. The extent of gene transfer by transduction and conjugation has been considered insufficient to disrupt the clonal framework of E. coli populations (Levin, 1981; Whittam et al., $1983 \mathrm{~b}$ ), although nucleotide sequence evidence suggests 
Table 1. Allele profiles, auxotypes and serovars for 89 ETs of N. gonorrhoeae

\begin{tabular}{|c|c|c|c|c|c|c|c|c|c|c|c|c|c|c|c|}
\hline \multirow[b]{2}{*}{ ET } & \multirow[b]{2}{*}{ Strain } & \multicolumn{9}{|c|}{ Allele at indicated enzyme locus:* } & \multirow{2}{*}{$\begin{array}{l}\text { No. of } \\
\text { isolates }\end{array}$} & \multirow{2}{*}{ Source $\dagger$} & \multirow[b]{2}{*}{ Year } & \multirow[b]{2}{*}{ Auxotype } & \multirow[b]{2}{*}{ Serovar $\ddagger$} \\
\hline & & GD2 & IDH & GOT & PGI & MAE & G6P & ALP & LAP & ADK & & & & & \\
\hline 1 & 31423 & 2 & 3 & 4 & 3 & 1 & 3 & 2 & 2 & 2 & (35) & Denmark & 1963 & $\mathrm{P}^{-}$ & $1 \mathrm{~A}-1$ \\
\hline 1 & 56567 & 2 & 3 & 4 & 3 & 1 & 3 & 2 & 2 & 2 & & Denmark & 1963 & NR & $1 \mathrm{~B}-3$ \\
\hline 1 & $1 / 86$ & 2 & 3 & 4 & 3 & 1 & 3 & 2 & 2 & 2 & & Botswana & 1986 & NR & 1B-3 \\
\hline 1 & 3091 & 2 & 3 & 4 & 3 & 1 & 3 & 2 & 2 & 2 & & Dakar & 1982 & $\mathbf{P}^{-}$ & $1 \mathrm{~B}-3$ \\
\hline 1 & 3096 & 2 & 3 & 4 & 3 & 1 & 3 & 2 & 2 & 2 & & Dakar & 1982 & NR & - \\
\hline 1 & 10 Godhab & 2 & 3 & 4 & 3 & 1 & 3 & 2 & 2 & 2 & & Greenland & 1987 & $\mathbf{P}^{-}$ & $1 \mathrm{~A}-14$ \\
\hline 1 & 16 Godhab & 2 & 3 & 4 & 3 & 1 & 3 & 2 & 2 & 2 & & Greenland & 1987 & NR & $1 \mathrm{~B}-20$ \\
\hline 1 & A9446/88 & 2 & 3 & 4 & 3 & 1 & 3 & 2 & 2 & 2 & & Norway & 1988 & - & - \\
\hline 1 & A9972/88 & 2 & 3 & 4 & 3 & 1 & 3 & 2 & 2 & 2 & & Norway & 1988 & $\mathrm{~A}^{-} \mathrm{H}^{-} \mathrm{U}^{-}$ & $1 B-3$ \\
\hline 1 & $024483 / 87$ & 2 & 3 & 4 & 3 & 1 & 3 & 2 & 2 & 2 & & Scotland & 1987 & $\mathrm{~A}^{-}$ & - \\
\hline 1 & $34083 / 87$ & 2 & 3 & 4 & 3 & 1 & 3 & 2 & 2 & 2 & & Scotland & 1987 & $\mathbf{P}^{-}$ & $1 \mathrm{~B}-3$ \\
\hline 1 & $3551 / 87$ & 2 & 3 & 4 & 3 & 1 & 3 & 2 & 2 & 2 & & Scotland & 1987 & NR & 1B-3 \\
\hline 1 & J317B & 2 & 3 & 4 & 3 & 1 & 3 & 2 & 2 & 2 & & Jamaica & - & $\mathbf{P}^{-}$ & - \\
\hline 1 & $\mathrm{~J} 326 \mathrm{~B}$ & 2 & 3 & 4 & 3 & 1 & 3 & 2 & 2 & 2 & & Jamaica & - & NR & 1B-3 \\
\hline 1 & J411B-2 & 2 & 3 & 4 & 3 & 1 & 3 & 2 & 2 & 2 & & Jamaica & - & $\mathbf{P}^{-} \mathbf{A}^{-}$ & 1A-8 \\
\hline 1 & SB3270 & 2 & 3 & 4 & 3 & 1 & 3 & 2 & 2 & 2 & & Thailand & 1988 & $\mathbf{P}^{-}$ & 1B-7 \\
\hline 1 & SB2961 & 2 & 3 & 4 & 3 & 1 & 3 & 2 & 2 & 2 & & W. Africa & 1988 & NR & 1B-6 \\
\hline 1 & SB2962 & 2 & 3 & 4 & 3 & 1 & 3 & 2 & 2 & 2 & & W. Africa & 1988 & NR & 1B-6 \\
\hline 1 & Medan 7 & 2 & 3 & 4 & 3 & 1 & 3 & 2 & 2 & 2 & & Indonesia & 1983 & $\mathrm{P}^{-}$ & $1 \mathrm{~A}-6$ \\
\hline 1 & Medan 11 & 2 & 3 & 4 & 3 & 1 & 3 & 2 & 2 & 2 & & Indonesia & 1983 & NR & $1 \mathrm{~A}-4$ \\
\hline 1 & Medan 21 & 2 & 3 & 4 & 3 & 1 & 3 & 2 & 2 & 2 & & Indonesia & 1983 & $\mathbf{P}^{-} \mathbf{A}^{-}$ & $1 B-13$ \\
\hline 1 & Medan 26 & 2 & 3 & 4 & 3 & 1 & 3 & 2 & 2 & 2 & & Indonesia & 1983 & $\mathrm{P}^{-}$ & $\rightarrow$ \\
\hline 1 & Medan 56 & 2 & 3 & 4 & 3 & 1 & 3 & 2 & 2 & 2 & & Indonesia & 1983 & $\mathrm{P}^{-}$ & 1B-6 \\
\hline 1 & Medan 60 & 2 & 3 & 4 & 3 & 1 & 3 & 2 & 2 & 2 & & Indonesia & 1983 & NR & $1 \mathrm{~A}-1$ \\
\hline 1 & JKD179 & 2 & 3 & 4 & 3 & 1 & 3 & 2 & 2 & 2 & & Australia & - & & - \\
\hline 1 & LDJ164 & 2 & 3 & 4 & 3 & 1 & 3 & 2 & 2 & 2 & & US & 1989 & $\mathbf{P}^{-} \mathbf{H}^{-}$ & 1B-7 \\
\hline 1 & 30991 & 2 & 3 & 4 & 3 & 1 & 3 & 2 & 2 & 2 & & US & 1989 & NR & 1B-18 \\
\hline 1 & 36151 & 2 & 3 & 4 & 3 & 1 & 3 & 2 & 2 & 2 & & US & 1989 & NR & - \\
\hline 1 & 5615 & 2 & 3 & 4 & 3 & 1 & 3 & 2 & 2 & 2 & & Ireland & 1986 & NR & 1B-3 \\
\hline 1 & 5188 & 2 & 3 & 4 & 3 & 1 & 3 & 2 & 2 & 2 & & Ireland & 1985 & $\mathrm{~A}^{-}$ & 1B-3 \\
\hline 1 & 5936 & 2 & 3 & 4 & 3 & 1 & 3 & 2 & 2 & 2 & & Ireland & 1985 & $\mathrm{P}^{-}$ & $1 \mathrm{~A}-7$ \\
\hline 1 & 8030 & 2 & 3 & 4 & 3 & 1 & 3 & 2 & 2 & 2 & & Ireland & 1984 & NR & 1B-16 \\
\hline 1 & 4513 & 2 & 3 & 4 & 3 & 1 & 3 & 2 & 2 & 2 & & Ireland & - & NR & $1 A-5$ \\
\hline 1 & 4539 & 2 & 3 & 4 & 3 & 1 & 3 & 2 & 2 & 2 & & Ireland & 1985 & $\mathbf{P}^{-}$ & 1B-3 \\
\hline 1 & 6 & 2 & 3 & 4 & 3 & 1 & 3 & 2 & 2 & 2 & & Ireland & 1988 & NR & - \\
\hline 2 & 537 & 2 & 3 & 4 & 5 & 1 & 3 & 2 & 2 & 2 & (3) & Ireland & 1987 & NR & 1B-2 \\
\hline 3 & $36736 / 87$ & 2 & 3 & 4 & 2 & 1 & 3 & 2 & 2 & 2 & (12) & Scotland & 1987 & $\mathbf{A}^{-}$ & $1 B-3$ \\
\hline 4 & SB2701 & 2 & 3 & 4 & 4 & 1 & 3 & 2 & 2 & 2 & (5) & Thailand & - & NR & - \\
\hline 5 & Godhab/17 & 2 & 3 & 4 & 1 & 1 & 3 & 2 & 2 & 2 & (1) & Greenland & 1987 & $\mathbf{P}^{-}$ & $1 B-30$ \\
\hline 6 & HNL890102 & 4 & 3 & 4 & 2 & 1 & 3 & 2 & 2 & 2 & (5) 11 & US & 1989 & $\mathbf{P}^{-} \mathrm{H}^{-}$ & $1 \mathrm{~B}-11$ \\
\hline 7 & JKD174 & 2 & 1 & 4 & 1 & 1 & 3 & 2 & 2 & 2 & (2) 1 & Australia & - & NR & $1 \mathrm{~A}-8$ \\
\hline 8 & SB2629 & 2 & 3 & 1 & 4 & 1 & 3 & 2 & 2 & 2 & (1) & Thailand & - & NR & $1 \mathrm{~B}-7$ \\
\hline 9 & $56914 / 15$ & 2 & 3 & 3 & 4 & 1 & 3 & 2 & 2 & 2 & (2) 1 & Denmark & 1963 & NR & - \\
\hline 10 & 30990 & 1 & 3 & 2 & 4 & 1 & 3 & 2 & 2 & 2 & (1) 1 & US & 1989 & - & $1 \mathrm{~A}-2$ \\
\hline 11 & Godhab 7 & 2 & 2 & 4 & 3 & 1 & 2 & 2 & 2 & 2 & (3) & Greenland & 1987 & $\mathbf{P}^{-}$ & - \\
\hline 12 & J244A & 2 & 3 & 4 & 3 & 1 & 2 & 2 & 2 & 2 & (1) J & Jamaica & - & NR & $1 B-3$ \\
\hline 13 & 608 & 2 & 3 & 4 & 2 & 1 & 2 & 2 & 2 & 1 & (1) $\mathrm{l}$ & Ireland & 1984 & $\mathrm{P}^{-}$ & $1 \mathrm{~B}-3$ \\
\hline 14 & 33758 & 2 & 3 & 4 & 2 & 1 & 2 & 2 & 2 & 2 & (2) & US & 1989 & $\mathbf{P}^{-}$ & $1 \mathrm{~A}-4$ \\
\hline 15 & JKD121 & 2 & 3 & 4 & 2 & 1 & 4 & 2 & 2 & 2 & (2) & Australia & - & $\mathbf{P}^{-}$ & 1B-2 \\
\hline 16 & 3081 & 2 & 3 & 4 & 3 & 1 & 3 & 2 & 2 & 3 & (3) 1 & Dakar & 1982 & $\mathbf{P}^{-}$ & $1 B-4$ \\
\hline 17 & 35870 & 2 & 3 & 2 & 3 & 1 & 3 & 2 & 2 & 3 & (4) & US & 1989 & $\mathrm{P}^{-} \mathrm{H}^{-}$ & 1B-1 \\
\hline 18 & A9122/88 & 2 & 3 & 4 & 5 & 1 & 3 & 2 & 2 & 3 & (3) 1 & Norway & 1988 & $\mathbf{P}^{-} \mathbf{A}^{-}$ & $1 \mathrm{~A}-4$ \\
\hline 19 & G3 & 2 & 1 & 4 & 3 & 1 & 3 & 2 & 2 & 3 & (1) I & Ireland & 1988 & $\mathrm{~A}^{-} \mathrm{H}^{-}$ & $1 \mathrm{~A}-1$ \\
\hline 20 & LDJ 244 & 2 & 3 & 2 & 2 & 1 & 3 & 2 & 2 & 1 & (1) & US & 1989 & $\mathbf{P}^{-} \mathbf{H}^{-}$ & $1 A-4$ \\
\hline 21 & 3090 & 4 & 3 & 1 & 3 & 1 & 3 & 2 & 2 & 2 & (2) I & Dakar & 1982 & NR & $1 A-19$ \\
\hline 22 & 57524 & 2 & 3 & 2 & 3 & 1 & 3 & 2 & 2 & 2 & (4) & Denmark & 1963 & NR & - \\
\hline 23 & Medan 14 & 2 & 3 & 2 & 3 & 1 & 3 & 2 & 3 & 2 & (1) 1 & Indonesia & 1983 & $\mathbf{P}^{-}$ & 1B-2 \\
\hline 24 & SB3077 & 2 & 3 & 2 & 3 & 1 & 3 & 2 & 1 & 2 & (2) 1 & Nigeria & - & $\mathbf{P}^{-}$ & - \\
\hline 25 & 5330 & 3 & 3 & 2 & 3 & 1 & 3 & 2 & 3 & 2 & (1) 1 & Ireland & - & NR & $1 \mathrm{~A}-15$ \\
\hline 26 & JKD185 & 2 & 3 & 3 & 3 & 1 & 3 & 2 & 2 & 2 & (7) & Australia & - & $\mathbf{P}^{-}$ & - \\
\hline 27 & $37178 / 87$ & 2 & 2 & 3 & 3 & 1 & 3 & 2 & 2 & 2 & (1) & Scotland & 1987 & NR & 1B-14 \\
\hline 28 & SB3326 & 2 & 2 & 2 & 3 & 1 & 3 & 2 & 2 & 2 & (1) & Grenada & - & NR & - \\
\hline 29 & 3097 & 2 & 4 & 4 & 3 & 1 & 3 & 2 & 2 & 2 & (3) 1 & Dakar & 1982 & NR & 1B-6 \\
\hline 30 & $\mathrm{Sb}$ & 2 & 4 & 4 & 3 & 1 & 3 & 3 & 2 & 2 & (1) & Unknown & - & $\mathbf{P}^{-}$ & $1 \mathrm{~B}-6$ \\
\hline 31 & J186B & 2 & 4 & 4 & 3 & 1 & 3 & 2 & 3 & 2 & (2) J & Jamaica & - & NR & $1 B-4$ \\
\hline
\end{tabular}


Table 1 (cont.)

\begin{tabular}{|c|c|c|c|c|c|c|c|c|c|c|c|c|c|c|c|}
\hline \multirow[b]{2}{*}{ ET } & \multirow[b]{2}{*}{ Strain } & \multicolumn{9}{|c|}{ Allele at indicated enzyme locus:* } & \multirow{2}{*}{$\begin{array}{l}\text { No. of } \\
\text { isolates }\end{array}$} & \multirow{2}{*}{ Source $\dagger$} & \multirow[b]{2}{*}{ Year } & \multirow[b]{2}{*}{ Auxotype } & \multirow[b]{2}{*}{ Serovar } \\
\hline & & GD2 & IDH & GOT & PGI & MAE & G6P & ALP & LAP & ADK & & & & & \\
\hline 32 & SB3268 & 2 & 4 & 2 & 3 & 1 & 1 & 2 & 2 & 2 & (1) & Thailand & - & NR & $1 \mathrm{~B}-30$ \\
\hline 33 & $16328 / 87$ & 2 & 3 & 4 & 3 & 1 & 3 & 3 & 2 & 2 & (9) & Scotland & 1987 & NR & IA-4 \\
\hline 33 & $16301 / 87$ & 2 & 3 & 4 & 3 & 1 & 3 & 3 & 2 & 2 & & Scotland & 1987 & NR & $1 \mathrm{~A}-4$ \\
\hline 34 & 3075 & 2 & 3 & 4 & 3 & 1 & 3 & 1 & 2 & 2 & (6) 1 & Dakar & 1982 & NR & $1 A-11$ \\
\hline 35 & Medan 23 & 4 & 3 & 4 & 3 & 1 & 3 & 1 & 2 & 2 & (4) & Indonesia & 1983 & NR & $1 \mathrm{~B}-1$ \\
\hline 36 & 3084 & 3 & 3 & 4 & 3 & 1 & 3 & 1 & 2 & 2 & (3) 1 & Dakar & 1982 & NR & - \\
\hline 37 & SB3038 & 3 & 3 & 4 & 3 & 1 & 4 & 1 & 2 & 2 & (2) & Thailand & - & NR & 1B-1 \\
\hline 38 & 5793 & 3 & 3 & 2 & 3 & 1 & 3 & 1 & 2 & 2 & (1) 1 & Ireland & - & $\mathrm{A}^{-}$ & $1 A-6$ \\
\hline 39 & 3094 & 2 & 3 & 4 & 3 & 1 & 3 & 1 & 1 & 2 & (2) & Dakar & 1982 & NR & - \\
\hline 40 & JKD213 & 2 & 3 & 4 & 3 & 1 & 3 & 1 & 3 & 2 & (11) & Australia & - & $\mathbf{P}^{-} \mathbf{A}^{-}$ & 1B-2 \\
\hline 41 & 3078 & 2 & 3 & 4 & 3 & 1 & 3 & 1 & 1 & 2 & (1) 1 & Dakar & 1982 & $\mathbf{P}^{-}$ & - \\
\hline 42 & 4354 & 3 & 3 & 4 & 3 & 1 & 3 & 2 & 2 & 2 & (4) I & Ireland & 1985 & NR & - \\
\hline 43 & $\mathrm{C} 5$ & 3 & 3 & 4 & 3 & 1 & 3 & 2 & 1 & 2 & (1) & Canada & - & $\mathrm{A}^{-} \mathrm{H}^{-} \mathrm{U}^{-}$ & - \\
\hline 44 & $17 / 86$ & 3 & 3 & 4 & 3 & 1 & 3 & 2 & 1 & 3 & (1) 1 & Botswana & 1986 & $\mathbf{P}^{-}$ & - \\
\hline 45 & 3086 & 3 & 3 & 4 & 3 & 1 & 2 & 2 & 3 & 2 & (1) I & Dakar & 1982 & NR & $1 \mathrm{~A}-1$ \\
\hline 46 & 4370 & 3 & 3 & 4 & 2 & 1 & 3 & 3 & 2 & 2 & (1) I & Ireland & - & NR & 1B-13 \\
\hline 47 & 415 & 3 & 3 & 4 & 3 & 1 & 3 & 3 & 2 & 2 & (2) 1 & Ireland & 1986 & NR & $1 B-6$ \\
\hline 48 & J367B-2 & 4 & 3 & 4 & 1 & 1 & 3 & 3 & 2 & 2 & (1) J & Jamaica & - & $\mathrm{P}^{-}$ & $1 \mathrm{~A}-2$ \\
\hline 49 & 5050 & 4 & 3 & 4 & 2 & 1 & 3 & 3 & 2 & 3 & (1) 1 & Ireland & 1986 & NR & - \\
\hline 50 & $15 / 86$ & 2 & 3 & 4 & 2 & 1 & 3 & 3 & 4 & 2 & (3) 1 & Botswana & 1986 & $\mathbf{P}^{-} \mathbf{A}^{-}$ & 1B-6 \\
\hline 51 & Godhab 8 & 2 & 3 & 4 & 3 & 1 & 3 & 2 & 4 & 2 & (1) & Greenland & 1987 & $\mathrm{P}^{-}$ & - \\
\hline 52 & 2329 & 3 & 3 & 4 & 2 & 1 & 3 & 3 & 1 & 2 & (1) I & Ireland & 1987 & $\mathbf{P}^{-}$ & 1B-1 \\
\hline 53 & $14 / 86$ & 2 & 3 & 4 & 2 & 1 & 3 & 3 & 1 & 2 & (1) 1 & Botswana & 1986 & $\mathbf{P}^{-}$ & $1 \mathrm{~A}-1$ \\
\hline 54 & 7993 & 2 & 3 & 4 & 2 & 1 & 3 & 2 & 1 & 2 & (1) I & Ireland & 1985 & NR & 1B-3 \\
\hline 55 & $32211 / 87$ & 2 & 3 & 4 & 2 & 1 & 3 & 1 & 2 & 2 & (1) & Scotland & 1987 & NR & - \\
\hline 56 & HNL890105 & 2 & 3 & 4 & 2 & 1 & 3 & 3 & 2 & 2 & (2) & US & 1989 & $\mathbf{P}^{-} \mathbf{A}^{-} \mathbf{U}^{-}$ & 1B-16 \\
\hline 57 & J49B & 2 & 3 & 4 & 2 & 1 & 1 & 3 & 2 & 3 & (1) J & Jamaica & - & $\mathrm{P}^{-}$ & 1B-2 \\
\hline 58 & $28517 / 87$ & 2 & 3 & 3 & 2 & 1 & 3 & 3 & 2 & 2 & (2) $s$ & Scotland & 1987 & - & $1 \mathrm{~A}-15$ \\
\hline 59 & $\mathrm{~J} 140 \mathrm{~A}$ & 2 & 2 & 3 & 2 & 1 & 3 & 3 & 2 & 2 & (1) $\mathrm{J}$ & Jamaica & - & NR & - \\
\hline 60 & $6 / 86$ & 2 & 2 & 3 & 3 & 1 & 3 & 3 & 2 & 2 & (1) 1 & Botswana & 1986 & $\mathbf{P}^{-}$ & $1 \mathrm{~B}-3$ \\
\hline 61 & 35871 & 2 & 2 & 4 & 3 & 1 & 3 & 3 & 2 & 2 & (2) & US & 1989 & $\mathbf{P}^{-} \mathbf{A}^{-}$ & 1B-1 \\
\hline 62 & LDJ 160 & 2 & 2 & 4 & 2 & 1 & 3 & 3 & 2 & 2 & (1) & US & 1989 & $\mathrm{P}^{-}$ & $1 \mathrm{~B}-7$ \\
\hline 63 & Godhab 24 & 2 & 2 & 4 & 3 & 1 & 3 & 1 & 2 & 2 & (2) & Greenland & 1987 & NR & $1 \mathrm{~B}-3$ \\
\hline 64 & $18 / 86$ & 2 & 3 & 2 & 3 & 1 & 3 & 3 & 2 & 2 & (3) $I$ & Botswana & 1986 & NR & $1 \mathrm{~A}-6$ \\
\hline 65 & A9706/88 & 2 & 3 & 2 & 4 & 1 & 3 & 3 & 2 & 2 & (1) 1 & Norway & 1988 & $\mathbf{P}^{-}$ & $1 B-3$ \\
\hline 66 & J198A-1 & 2 & 3 & 4 & 4 & 1 & 3 & 3 & 2 & 2 & (1) J & Jamaica & - & $\mathrm{P}^{-}$ & 1B-16 \\
\hline 67 & Medan 2 & 2 & 4 & 4 & 1 & 1 & 3 & 3 & 3 & 2 & (1) I & Indonesia & 1983 & $\mathbf{P}^{-}$ & $1 A-6$ \\
\hline 68 & $26778 / 87$ & 2 & 3 & 4 & 1 & 1 & 3 & 3 & 3 & 2 & (1) $s$ & Scotland & 1987 & NR & - \\
\hline 69 & Medan 32 & 2 & 3 & 4 & 3 & 1 & 3 & 3 & 3 & 2 & (8) I & Indonesia & 1983 & $\mathbf{P}^{-}$ & $1 \mathrm{~A}-6$ \\
\hline 70 & 8234 & 2 & 3 & 3 & 3 & 1 & 3 & 3 & 3 & 2 & (2) I & Ireland & - & $\mathrm{A}^{-} \mathbf{H}^{-} \mathrm{U}^{-}$ & - \\
\hline 71 & 5865 & 2 & 3 & 2 & 2 & 1 & 3 & 3 & 3 & 2 & (3) 1 & Ireland & 1985 & $\mathrm{P}^{-}$ & $1 \mathrm{~B}-2$ \\
\hline 72 & 3076 & 2 & 3 & 4 & 2 & 1 & 3 & 1 & 3 & 2 & (1) I & Dakar & 1982 & $\mathbf{P}^{-}$ & $1 \mathrm{~B}-1$ \\
\hline 73 & 8187 & 2 & 3 & 4 & 5 & 1 & 3 & 1 & 3 & 2 & (1) I & Ireland & 1984 & NR & 1B-4 \\
\hline 74 & $19 / 86$ & 2 & 3 & 4 & 5 & 1 & 3 & 2 & 3 & 2 & (1) $\mathrm{I}$ & Botswana & 1986 & $\mathbf{P}^{-} \mathbf{H}^{-}$ & 1B-5 \\
\hline 75 & 9294 & 4 & 2 & 4 & 2 & 1 & 3 & 1 & 2 & 2 & (1) I & Ireland & - & NR & 1B-6 \\
\hline 76 & JKD192 & 2 & 2 & 4 & 2 & 1 & 3 & 2 & 3 & 2 & (2) $A$ & Australia & - & NR & $1 \mathrm{~B}-6$ \\
\hline 77 & 31830 & 2 & 2 & 4 & 2 & 1 & 3 & 2 & 3 & 1 & (1) $\mathrm{s}$ & Scotland & 1987 & $\mathrm{H}^{-}$ & 1B-29 \\
\hline 78 & $34732 / 87$ & 2 & 2 & 4 & 2 & 1 & 3 & 2 & 2 & 2 & (1) $\mathrm{s}$ & Scotland & 1987 & $\mathbf{P}^{-}$ & $1 \mathrm{~A}-4$ \\
\hline 79 & $12 / 86$ & 2 & 2 & 4 & 2 & 1 & 3 & 4 & 4 & 2 & (1) $\mathrm{E}$ & Botswana & 1986 & NR & 1B-1 \\
\hline 80 & $34583 / 87$ & 2 & 2 & 2 & 5 & 1 & 3 & 2 & 3 & 2 & (1) $\mathrm{s}$ & Scotland & 1987 & NR & $1 \mathrm{~B}-13$ \\
\hline 81 & $27422-88$ & 2 & 3 & 4 & 3 & 1 & 4 & 2 & 3 & 1 & (3) $\mathrm{s}$ & Sweden & 1988 & - & $1 A-1$ \\
\hline 82 & $9 / 86$ & 2 & 3 & 4 & 3 & 1 & 2 & 2 & 3 & 1 & (1) $\mathrm{E}$ & Botswana & 1986 & NR & - \\
\hline 83 & $54777 / 78$ & 2 & 3 & 4 & 3 & 1 & 3 & 2 & 4 & 1 & (2) I & Denmark & 1963 & $\mathbf{P}^{-}$ & $1 \mathrm{~B}-3$ \\
\hline 84 & $\mathrm{Cl}$ & 2 & 3 & 4 & 1 & 1 & 2 & 4 & 3 & 1 & (1) & Canada & - & $\mathrm{A}^{-}$ & $1 \mathrm{~A}-2$ \\
\hline 85 & Unknown & 2 & 3 & 4 & 4 & 1 & 1 & 3 & 2 & 1 & (1) I & Ireland & 1986 & NR & $1 \mathrm{~A}-1$ \\
\hline 86 & SB2980 & 4 & 3 & 2 & 1 & 1 & 4 & 2 & 2 & 2 & (1) 2 & Zambia & - & $\mathrm{P}^{-}$ & 1A-1 \\
\hline 87 & SFO890202 & 3 & 3 & 3 & 5 & 1 & 4 & 2 & 2 & 2 & (1) $\mathrm{I}$ & US & 1989 & - & - \\
\hline 88 & POR890201 & 4 & 3 & 3 & 3 & 1 & 3 & 1 & 3 & 2 & (1) I & US & 1989 & $\mathrm{P}^{-}$ & 1B-1 \\
\hline 89 & 30993 & 3 & 4 & 3 & 3 & 1 & 4 & 2 & 3 & 2 & (1) $\mathrm{I}$ & US & 1989 & $\mathbf{P}^{-}$ & 1B-1 \\
\hline
\end{tabular}

* For abbreviations, see Methods.

† Strains from Botswana, Denmark, Indonesia, Greenland and Dakar were provided by I. Lind. Strains from Thailand, Nigeria and Zambia were supplied by the PHLS, Bristol, UK. Strains from Australia were supplied by L. Muir, strains from Scotland by H. Young and strains from the US by J. Schwebke. The isolates from Norway were provided by E. Falk, those from Jamaica were provided by J. Dillon and the remaining isolates from Ireland were provided by A. Rosney.

$\ddagger$ Serovars were determined from reaction patterns with monoclonal antibodies according to the scheme of Knapp et al. (1984). -, Serovar not determined. 
that localized recombination does occur in E. coli (Dykhuizen \& Green, 1991; Barcak \& Wolf, 1988; Stoltzfus et al., 1988; Milkman \& Bridges, 1990) and in other bacteria (Maynard Smith et al., 1991).

Values of diversity from electrophoretic data indicate that bacteria which are naturally competent for transformation (such as Bacillus, Streptococcus, Neisseria and Haemophilus) are genetically more variable than nontransformable bacteria (Selander et al., 1987). Levels of diversity within Neisseria meningitidis populations are greater than those reported for other species examined (Caugant et al., 1987), and both sequence data and electrophoretic data have shown evidence of recombination in N. meningitidis populations (Zhou \& Spratt, 1992; Caugant et al., 1986, 1990).

Recent studies suggest that recombination may be more frequent in some bacterial species; tests of linkage disequilibrium reveal that recombination is more frequent in both Bacillus subtilis (Istock et al., 1992) and Rhizobium leguminosarum (Souza et al., 1992) than in $E$. coli. Our results indicate that $N$. gonorrhoeae, unlike all pathogens so far examined, has a non-clonal population structure, implying extensive recombination in nature.

\section{Methods}

Bacterial isolates. The 227 strains of $N$. gonorrhoeae studied were isolated between 1963 and 1989. The collection includes 24 strains from various locations in the United States isolated in 1989, and 53 strains from Ireland, isolated between 1984 and 1988. Thirty of the strains were isolated between 1982 and 1986 from various locations in Africa. The collection also includes 12 strains from Greenland isolated in 1987, 13 strains from Indonesia isolated in 1983, 23 Scottish strains isolated in 1987 and 21 strains from Thailand isolated in 1988. A total of 15 strains were obtained from Scandinavia, 9 of which were isolated in Denmark in 1963. The remaining 34 strains were from Jamaica and Australia (year of isolation unknown) and a pair of strains from Canada (1988) were also examined. There is little epidemiological information available for the strains. The isolates from Denmark, Botswana, Greenland and Dakar comprise non-consecutive patient isolates and the strains from Indonesia were isolated from female prostitutes. Two pairs of strains were epidemiologically related: strains $16328 / 87$ and 16301/87 from Scotland, and strains SB2961 and SB2962 from W. Africa (Table 1).

Electrophoresis of enzymes. Each isolate was grown in GC broth, whose constituents were the same as GC agar (Oxoid), with the omission of agar and the inclusion of $0.03 \mathrm{M}-\mathrm{NaHCO}_{3}, 0.03 \mathrm{M}$-glucose and yeast extract $\left(4 \mathrm{~g} \mathrm{l}^{-1}\right)$. Broth was dispensed into hypovials (Pierce Warner) into which $\mathrm{CO}_{2}$ was injected at a concentration of $5 \%(\mathrm{v} / \mathrm{v})$. Cells were harvested by centrifugation at $5000 \mathrm{~g}$ for $5 \mathrm{~min}$ at $4{ }^{\circ} \mathrm{C}$. After

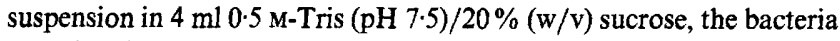
were lysed by storage at $-20^{\circ} \mathrm{C}$ overnight. The extracts were then centrifuged at $13000 \mathrm{~g}$ for $10 \mathrm{~min}$ to remove cellular debris and stored at $-20^{\circ} \mathrm{C}$ in $20 \mu \mathrm{l}$ aliquots.

Soluble enzyme extracts of each isolate were separated on $11 \%(\mathrm{w} / \mathrm{v})$ starch (Sigma) gels using the method described by Selander et al. (1986). The electrophoretic buffer systems and the enzymes assayed were as follows: (i) Tris/citrate, $\mathrm{pH} 8.0$ [glutamate dehydrogenase (GD2), isocitrate dehydrogenase (IDH), glutamic-oxaloacetic trans- aminase (GOT)]; (ii) Tris/maleate, $\mathrm{pH} 7.4$ [alkaline phosphatase (ALP), leucine aminopeptidase (LAP), adenylate kinase (ADK)]; (iii) potassium phosphate, $\mathrm{pH} 7.0$ [glucose-6-phosphate dehydrogenase (G6P), phosphoglucose isomerase (PGI), malic enzyme (MAE)].

Distinctive mobility variants of each enzyme were numbered in order of increasing rate of anodal migration and were equated with alleles of the corresponding structural genes. Each isolate was characterized by its combination of alleles at the nine enzyme loci (Table 1). Distinctive combinations of alleles, corresponding to unique multilocus genotypes, were designated as electrophoretic types (ETs). A table which lists the genotype, auxotype, serotype, date of isolation and geographic origin of each of the 227 isolates is available from the corresponding author.

Statistical procedures. Statistical analyses were performed using SPSS/PC + software (Norusis, 1986). Chi-square tests were performed as described by Weir (1990). An index to describe multilocus linkage disequilibrium in haploid populations based on the distribution of allelic mismatches between pairs of isolates was also calculated (Maynard Smith et al., 1993). This index, termed the Index of association $\left(I_{\mathrm{A}}\right)$ was calculated from the formula $I_{\mathrm{A}}=V_{\mathrm{o}} / V_{\mathrm{e}}-1$, where $V_{\mathrm{o}}$ is the variance in mismatches observed for the sample and $V_{\mathrm{e}}$ is the variance in mismatches expected in a population at linkage equilibrium. For populations in linkage equilibrium $V_{\mathrm{o}}=V_{\mathrm{e}}$ and $I_{\mathrm{A}}$ is not significantly different from zero.

Serological classification. One hundred and seventy-one isolates were serologically characterized by coagglutination using monoclonal antibodies to protein I (PI) as described by Tam et al. (1982). Isolates were classified as being PI class A (WI) or B (WII/WIII) and further subdivided into different serovars by reaction patterns with monoclonal antibodies specific for protein IA and IB (Knapp et al., 1984). The isolates were serotyped at the Neisseria Reference Laboratory, Seattle, Washington, USA.

Auxotypes. The isolates were auxotyped using the system described by Copley \& Egglestone (1983). The strains were tested for their requirements for proline $\left(\mathrm{P}^{-}\right)$, arginine $\left(\mathrm{A}^{-}\right)$, hypoxanthine $\left(\mathrm{H}^{-}\right)$and uracil $\left(\mathrm{U}^{-}\right)$or combinations of these requirements. Isolates with no requirements for these nutrients were classified as prototrophic (NR). A total of 202 isolates were auxotyped (89\%).

\section{Results}

\section{Electrophoretic types and genetic diversity}

The 227 isolates of $N$. gonorrhoeae comprised 89 distinct nine-locus electrophoretic genotypes (ETs). One of the enzymes (MAE) was monomorphic; the number of alleles for the remaining eight enzymes ranged from three to five. Of the $89 \mathrm{ETs}, 47$ were represented by single isolates and 42 by multiple isolates (range, 2 to 35 isolates; Table 1). The mean genetic diversity per locus was $0 \cdot 41$.

\section{Tests of linkage disequilibrium}

The 28 two-locus comparisons were tested for linkage disequilibrium by Fisher's exact test; none of them were significant $(0.01<P)$. The 28 comparisons were also tested for linkage disequilibrium by chi-squared analysis; $92.6 \%$ of them did not significantly depart from linkage equilibrium $(0.05<P<0.9)$.

Five four-allele combinations were then selected 
Table 2. Relative frequencies of four-locus allele combinations used in analysing linkage disequilibrium

\begin{tabular}{|c|c|c|c|c|c|c|}
\hline \multirow[b]{2}{*}{ Comparison } & \multicolumn{4}{|c|}{ Locus symbol* } & \multicolumn{2}{|c|}{$\begin{array}{l}\text { Frequency }(\%) \text { at which } \\
\text { comparison was }\end{array}$} \\
\hline & $\mathbf{a}$ & b & c & d & Expected $\dagger$ & Observed \\
\hline I & $\begin{array}{l}\mathrm{GD} 2 \text { '2' } \\
(0.744)\end{array}$ & $\begin{array}{l}\text { IDH'3' } \\
(0.744)\end{array}$ & $\begin{array}{l}\text { PGI'3' } \\
(0.50)\end{array}$ & $\begin{array}{l}\text { G6P'3’ } \\
(0.822)\end{array}$ & $22 \cdot 7$ & 19 \\
\hline II & $\begin{array}{l}\text { IDH '4' } \\
(0 \cdot 078)\end{array}$ & $\begin{array}{l}\text { GOT ' } 2 \text { ' } \\
(0 \cdot 167)\end{array}$ & $\begin{array}{l}\text { PGI ' } 3 \text { ' } \\
(0.50)\end{array}$ & $\begin{array}{c}\text { ALP'2' } \\
(0.555)\end{array}$ & 0.4 & $1 \cdot 1$ \\
\hline III & $\begin{array}{l}\text { GD2 '2' } \\
(0.744)\end{array}$ & $\begin{array}{l}\text { GOT '4' } \\
(0 \cdot 70)\end{array}$ & $\begin{array}{l}\operatorname{ALP}{ }^{\prime} 3 \\
(0 \cdot 278)\end{array}$ & $\begin{array}{l}\text { LAP ‘ } 3 \text { ' } \\
(0 \cdot 244)\end{array}$ & 3.5 & $3 \cdot 3$ \\
\hline IV & $\begin{array}{l}\text { GD2 ‘ } 3 \text { ' } \\
(0.144)\end{array}$ & $\begin{array}{l}\text { IDH ‘3’ } \\
(0.744)\end{array}$ & $\begin{array}{l}\text { GOT '4' } \\
(0 \cdot 70)\end{array}$ & $\begin{array}{l}\text { PGI '3' } \\
(0.50)\end{array}$ & $3 \cdot 7$ & $7 \cdot 7$ \\
\hline V & $\begin{array}{l}\text { IDH ‘ } 2 \text { ' } \\
(0 \cdot 156)\end{array}$ & $\begin{array}{l}\text { GOT '4' } \\
(0 \cdot 70)\end{array}$ & $\begin{array}{l}\text { PGI '2' } \\
(0 \cdot 278)\end{array}$ & $\begin{array}{l}\text { ALP'3' } \\
(0.278)\end{array}$ & 0.8 & $1 \cdot 1$ \\
\hline
\end{tabular}

* The relative frequencies of the alleles in the sample of 89 ETs are shown in parentheses.

$\dagger$ The expected frequency of each comparison was determined from the products of allele frequencies.

(Table 2) and the frequency at which these combinations were observed was compared to the frequencies expected under conditions of random assortment. This analysis was similar to that performed on $E$. coli by Whittam $e t$ al. $(1983 a)$; however, the allele combinations selected in this study were not chosen from a principal coordinates analysis, but were selected arbitrarily. Depending on whether the designated allele was present or absent at the locus in question, 16 possible allele combinations resulted. The expected frequency was computed from the products of allele frequencies. The observed frequency of the combinations among each of the 89 ETs was compared to that expected if alleles occurred independently in ETs. Most of the four-allele combinations were at values close to the proportions expected from allele frequencies alone. For example, the four-allele combination GD2 '2' IDH '3' PGI '3' G6P '3' accounted for $19 \%$ of the electrophoretic types; however, this combination was slightly less than that predicted from allele frequencies $(22.7 \%)$. Similarly the combinations IDH '4' GOT '2' PGI ' 3 ' ALP '2' and IDH ' 2 ' GOT ' 4 ' PGI ' 2 ' ALP ' 3 ' comprised $1.1 \%$ of the genotypes; however, both combinations were expected at frequencies of $0.4 \%$ and $0.8 \%$ respectively (Table 2).

An index to quantify multilocus linkage disequilibrium in bacterial populations, based on the distribution of allelic mismatches, was also calculated. This index, termed the index of association $\left(I_{\mathrm{A}}\right)$, measures the ratio of the variance in mismatches observed for the data set, $V_{0}$, to the variance expected in a corresponding population at linkage equilibrium, $V_{\mathrm{e}}$ (Maynard Smith et al., 1993). The index of association focuses on the complete data set and not on specific allele combinations, and is, therefore, an accurate measure of linkage disequilibrium. The value of the index of association is equal to zero for a population in linkage equilibrium, and differs significantly from zero if there is a significant association between alleles. For $N$. gonorrhoeae, the value of this index was not significantly different from zero $(0.04 \pm 0.09)$, suggesting a random assortment of alleles within the population. Since $N$. gonorrhoeae populations are in linkage equilibrium, it is not meaningful to construct a dendrogram to reveal genetic relationships from electrophoretic data.

\section{Frequently recovered genotypes}

Among the 89 genotypes, four ETs were each recovered more than nine times from strains isolated over a period of years. ET 1, the most common genotype, was represented by 35 strains $(15.4 \%)$ isolated between 1963 and 1989 from the United States, Indonesia, Ireland, Scotland, Greenland, Jamaica, Thailand, Africa and Scandinavia (Table 1). Recovery of the same ET from different continents over a period of time is generally considered to be an indication of clonality. However, in a panmictic population isolates of the same ET can arise by the random association of the most common alleles in the population. The frequency at which ET 1 was expected in the population was determined from the product of individual allele frequencies. ET 1 possessed the most predominant allele at each locus and this combination of alleles was expected in 32.2 strains if the population was in linkage equilibrium. ET 3, ET 33 and ET 40 were also recovered from diverse geographic locations over a period of years. Similarly, the frequency at which ET 3, ET 33 and ET 40 were recovered is not 
Table 3. Mean genetic diversity $(H)$ within localities

\begin{tabular}{|c|c|c|c|c|c|}
\hline Location & $\begin{array}{l}\text { No. of } \\
\text { isolates }\end{array}$ & $\begin{array}{c}\text { No. of } \\
\text { ETs }\end{array}$ & $\begin{array}{c}\text { Mean no. } \\
\text { of alleles }\end{array}$ & $H_{\mathrm{ISO}}^{\dagger}$ & $H_{\mathrm{ETs}} \dagger$ \\
\hline US & 26 & 22 & 3.33 & 0.356 & 0.379 \\
\hline Greenland & 12 & 9 & $2 \cdot 11$ & 0.217 & 0.218 \\
\hline Jamaica & 22 & 19 & 2.67 & 0.272 & 0.291 \\
\hline Scotland & 23 & 18 & $2 \cdot 33$ & 0.264 & 0.296 \\
\hline Thailand* & 22 & 16 & $2 \cdot 78$ & 0.270 & 0.275 \\
\hline Indonesia & 13 & 6 & 1.89 & 0.148 & 0.193 \\
\hline Dakar & 16 & 13 & $2 \cdot 33$ & 0.199 & 0.201 \\
\hline Botswana & 15 & 12 & $2 \cdot 67$ & 0.278 & 0.296 \\
\hline Australia & 12 & 10 & $2 \cdot 22$ & 0.190 & 0.203 \\
\hline Scandinavia & 14 & 11 & $2 \cdot 44$ & $0 \cdot 242$ & 0.282 \\
\hline Ireland & 53 & 33 & 3.22 & 0.296 & 0.338 \\
\hline
\end{tabular}

* The 22 strains were isolated in Thailand, Grenada, Nigeria, W. Africa and Zambia.

$\dagger H_{\mathrm{ISO}}$, genetic diversity among isolates; $H_{\mathrm{ETs}}$, genetic diversity among ETs.

significantly different $(P<0.75)$ from the frequency at which each was expected assuming a random association of alleles.

\section{Genetic variation in relation to geographic location}

The collection of strains was partitioned into separate groups based on geographic origin (Table 3). Among the collection of $89 \mathrm{ETs}, 33(37 \%)$ were represented by isolates from two or more countries and in each case the distribution was intercontinental. The genetic variability within isolates from specific geographic regions was as large as that in the whole population. However, two ETs were detected in single locations: ET 11 was exclusive to three isolates from Greenland, while ET 41 was observed only among four isolates from Ireland.

\section{Genetic variation in relation to auxotype}

The number of isolates of a given auxotype ranged from $1\left(\mathrm{AH}^{-}\right)$to $109(\mathrm{NR})$. Table 1 lists the auxotype for each of the 89 reference strains. Seven of the nine auxotypes were each represented by strains of several multilocus genotypes, many of which differed from one another by alleles at four or more loci. The other two auxotypes were represented by single isolates. Strains which were epidemiologically related were of similar auxotype (Table 1). The four ETs which were encountered repeatedly were each represented by strains of several auxotypes (Table 1, Table 4). The diversity within auxotypes was $58 \%$ of the total diversity, while $91 \%$ of the total diversity was represented by prototrophic isolates (NR).

\section{Genetic variation in relation to serovar}

The 227 isolates comprised 35 different serovars, 11 of which were each represented by 4 or more strains. Table
Table 4. Distribution of auxotypes and serovars within the four predominant ETs

\begin{tabular}{lccc}
\hline ET & $\begin{array}{c}\text { No. of } \\
\text { isolates }\end{array}$ & $\begin{array}{c}\text { No. of } \\
\text { auxotypes }\end{array}$ & $\begin{array}{c}\text { No.of } \\
\text { serovars }\end{array}$ \\
\hline ET 1 & 35 & 5 & 10 \\
ET 3 & 12 & 4 & 6 \\
ET 33 & 9 & 3 & 4 \\
ET 40 & 11 & 4 & 5 \\
\hline
\end{tabular}

1 lists the serovar for each of the 89 reference strains. Isolates of shared serovar were represented by a variety of ETs. Strains which were epidemiologically related shared serovar (Table 1). The four most common genotypes were represented by strains of different serovar (Table 1, Table 4). The diversity within serovars was $75 \%$ of the total diversity observed.

\section{Discussion}

$N$. gonorrhoeae is constitutively competent at all phases of growth (Biswas et al., 1982) and undergoes intraspecific transformation in the laboratory (Seifert et al., 1988); however, the extent to which transformation occurs in nature is unknown. Actual rates of recombination in natural populations cannot be estimated from presently available data. However, the statistical analysis of electrophoretic data enables a crude estimate of the extent of recombination to be made from the degree of linkage disequilibrium. Our study has focused on electrophoretic variation in nine loci. At present the positions of these nine loci on the gonococcal genomic map are unknown (Bihlmaier et al., 1991), but it is presumed that they are representative of the genome.

\section{Genetics of N. gonorrhoeae populations}

Our study has revealed linkage equilibrium in natural populations of $N$. gonorrhoeae. There was little evidence of association between pairs of loci, since $92 \%$ of twolocus combinations did not depart from linkage equilibrium. Similarly, five four-locus combinations of alleles were found at frequencies close to those expected under conditions of random assortment. The index of association value for $N$. gonorrhoeae did not differ significantly from zero, the value expected for populations in linkage equilibrium.

Since bacterial reproduction is asexual, for $N$. gonorrhoeae to achieve linkage equilibrium, the species must experience a high frequency of recombination relative to binary fission, to reduce the clonal structure certain to arise otherwise. Recombination in $N$. gonorrhoeae is most likely due to transformation, since transformation 
is the only known mechanism for the transfer of chromosomal genes in N. gonorrhoeae (Biswas et al., 1989) and presumably results in the frequent transfer of relatively small chromosomal segments. A second aspect is that gonococci must encounter other gonococcal genotypes; hence mixed infections with different gonococcal strains must be relatively common. However, the frequency at which mixed gonococcal infections occur, the actual rate of recombination, and the reason for such extensive recombination are, at present, unknown.

Our report of a pathogenic bacterium whose population structure is non-clonal contrasts with the many pathogenic and commensal species studied to date (Selander \& Musser, 1990), where evidence of linkage disequilibrium has resulted in clonality being considered the paradigm in bacterial population genetics. However, $B$. subtilis populations reveal only modest clonal structure (Istock et al., 1992), and a recent statistical analysis of electrophoretic data has revealed that population structures can range from strictly clonal to panmictic (Maynard Smith et al., 1993). An intermediate type of population structure has also been recognized in which the population is panmictic in the long term, but occasionally a highly successful ET arises, which spreads rapidly to produce a degree of linkage disequilibrium in the population. $N$. meningitidis populations are an example of this 'epidemic' population structure.

Obviously the pattern and extent of sampling has an important bearing on the observed population structure. Temporal and geographic isolation of genotypes can give rise to linkage disequilibrium in the presence of recombination (Souza et al., 1992). However, ecological isolation of genotypes can also give rise to linkage disequilibrium despite recombination. For example, if the factors governing infection are such that genotypes do not encounter one another, linkage disequilibrium may be evident since any recombination occurs between genetically similar strains. The difference in population structure between the related species $N$. gonorrhoeae and $N$. meningitidis possibly reflects the fact that mixed infections are more common in cases of gonorrhoea than meningitis; however, it is also possible that gonococci exchange genetic material more readily than meningococci. Alternatively, the difference in population structure between $N$. gonorrhoeae and $N$. meningitidis may be due to differences in sampling, raising the possibility that $N$. gonorrhoeae might have revealed an 'epidemic' population structure if strains from a regional epidemic were examined.

\section{Comparison with the population structure of B. subtilis}

Recent studies of a $B$. subtilis population taken from a single site have revealed only modest clonal structure (Istock et al., 1992). Statistical tests of association show that $92 \%$ of two-locus combinations of $N$. gonorrhoeae did not depart from linkage equilibrium, a value greater than that reported for $B$. subtilis populations $(76 \%)$, in which only slight linkage disequilibrium was observed. The shortage of two-locus haploid genotypes in natural populations of $N$. gonorrhoeae (and B. subtilis) contrasts markedly with $E$. coli populations, where restricted recombination results in a high association between pairs of loci (Caugant et al., 1981; Whittam \& Wilson, 1988).

The genotypic composition of populations varies geographically and temporally; ETs in high frequency in a geographic location at one time may be absent or in undetectable frequencies in other locations. Certain gonococcal genotypes were recovered at high frequency from temporally and geographically unassociated hosts. Four ETs were each recovered more than nine times and a single genotype, ET 1, accounted for $15.4 \%$ of the ETs. In $B$. subtilis populations the most frequent ET accounted for only $3 \%$ of the types (Istock et al., 1992). Evolutionary convergence to the same ET is generally considered unlikely and ETs are often presumed to mark clones, having resulted from a shared descent from a common ancestral cell (Selander \& Levin, 1980). In many species, the global recovery of strains of the same genotype is due primarily to restricted recombination among clonal lineages (Musser et al., 1988; Ochman \& Selander, 1984). For $N$. gonorrhoeae the reappearance of strains of the same ET could suggest the existence of specific clones, contrasting with the apparent linkage equilibrium. However, the repeated recovery of identical genotypes of $N$. gonorrhoeae is not at variance with evidence of linkage equilibrium, since each of the four most common genotypes were observed at frequencies close to those predicted from a random assortment of alleles. It is a consequence of linkage disequilibrium that the number of new ETs gradually decreases as the number of loci assayed increases. Hence, it is likely that an examination of the 35 ET 1 isolates by additional enzymes or DNA-based approaches would reveal a lack of genetic identity among isolates of shared genotype. Indeed, 30 of the ET 1 isolates have been further assessed by a combination of MLEE, gene fingerprinting and random-primer DNA typing (RAPD), which has revealed a lack of genetic identity among isolates of shared genotype, as expected from a population in linkage equilibrium (M. O'Rourke \& B. G. Spratt, unpublished).

\section{Consequences for epidemiology}

Our study has revealed no association between ETs and auxotype or serovar. Isolates of the same auxotype or serovar were of different ETs. Similarly, isolates of the same ET comprised several auxotypes and serovars. Serotypes are concordant with multilocus genotypes in 
many clonal species (Selander et al., 1990; Musser et al., 1988), although notable exceptions include $E$. coli (Achtman \& Pluschke, 1986) and L. pneumophila (Selander et al., 1985). In addition, serogroup, serotype and serosubtype do not correlate with electrophoretic type in serogroup B and serogroup $\mathrm{C}$ meningococci (Caugant et al., 1987; Wang et al., 1992); also, nucleotide sequence evidence for recombination in the P1 serosubtyping antigen has been reported (Feavers et al., 1992). Hence, the absence of any correlation between ET and serovar in $N$. gonorrhoeae is not surprising.

Furthermore, surface antigens are likely to be under strong selection and considerable diversity has been reported in many gonococcal surface antigens, including pilin genes (Seifert et al., 1988) and the outer-membrane protein P2 (Stern et al., 1986). There has been little information on the genetic relatedness between gonococcal isolates, and most epidemiological studies have focused on auxotype and serotype data (Sarafian \& Knapp, 1989). In this study $75 \%$ of the strains were represented by two auxotypes and the combination of auxotype and serovar revealed 79 different auxotype/ serovar classes, which provided less discrimination than MLEE.

Previous studies using MLEE have provided useful marker systems for epidemiology and have established population genetic frameworks to study the variation and distribution of typing characters (Selander et al., 1985, 1990; Musser et al., 1988). However, the evidence for extensive recombination in $N$. gonorrhoeae suggests that effective epidemiological typing of these bacteria will prove difficult. Unlike clonal species, genes in $N$. gonorrhoeae are likely to be constantly assorted into new combinations by recombination, with particular genotypes existing only transiently before they are disrupted by recombination. Although typing methods may be useful in the short term (for tracing the spread of a strain between contacts in a localized outbreak), they are likely to be of little use in the long term.

We thank Brian Spratt, Noel Smith and John Maynard Smith for critical reviews of the manuscript.

We gratefully acknowledge Jane Schwebke and the staff of the Neisseria Reference Laboratory (Seattle) for advice and assistance with serotyping, and we are indebted to Inga Lind, Jane Schwebke, Lalina Muir, Hugh Young, Edward Falk, Jo Ann Dillon and Angela Rosney for the provision of strains.

This study was supported by a grant from The Health Research Board, Ireland.

\section{References}

Achtman, M. \& Pluschke, G. (1986). Clonal analysis of descent and virulence among selected Escherichia coli. Annual Review of Microbiology 40, 185-210.
BarCak, G. J. \& Wolf, R. E., JR (1988). Comparative nucleotide sequence analysis of growth-rate regulated gnd alleles from natural isolates of Escherichia coli and from Salmonella typhimurium LT-2. Journal of Bacteriology 170, 372-379.

Bihlmaier, A., Romling, U., Meyer, T. F., Tummler, B. \& Gibis, C. P. (1991). Physical and genetic map of the Neisseria gonorrhoeae strain MS11-N198 chromosome. Molecular Microbiology 5, 25292539.

Biswas, G. D., Graves, J. F., Sox, T. F., Tenover, F. C. \& Sparling, P. F. (1982). Marker rescue by a homologous recipient plasmid during transformation of gonococci by a hybrid $\mathrm{Pc}^{\mathrm{r}}$ plasmid. Journal of Bacteriology 151, 77-82.

Biswas, G. D., Thompson, S. A. \& Sparling, P. F. (1989). Gene transfer in Neisseria gonorrhoeae. Clinical Microbiology Reviews 2 , suppl., S24-S28.

Caugant, D. A., Levin, B. R. \& Selander, R. K. (1981). Genetic diversity and temporal variation in the $E$. coli population of a human host. Genetics 98, 467-490.

Caugant, D. A., Bovre, K., Gaustad, R., Bryn, K., Holten, E., HøiвY, E. A. \& Frøholm, L. O. (1986). Multilocus genotypes determined by enzyme electrophoresis of Neisseria meningitidis isolated from patients with systemic disease and from healthy carriers. Journal of General Microbiology 132, 641-652.

Caugant, D. A., Mocca, L. F., Frasch, C. E., Frøholm, L. O., ZOLLINGER, W. A. \& Selander, R. K. (1987). Genetic structure of Neisseria meningitidis populations in relation to serogroup, serotype and outer membrane protein pattern. Journal of Bacteriology 169, 2781-2792.

Caugant, D. A., Bol, P., Høiby, E. A., Zanen, H. C. \& Frøholm, L. O. (1990). Clones of serogroup B Neisseria meningitidis causing systemic disease in the Netherlands, 1958-1986. Journal of Infectious Disease 162, 867-874.

Centres for Disease CONTROL (1992). Morbidity Mortality Weekly 40 , 893. Atlanta, GA: CDC.

Copley, C. G. \& EGGLestone, S. I. (1983). Auxotypes of Neisseria gonorrhoeae isolated in the United Kingdom. Journal of Medical Microbiology 16, 295-302.

DykHUIzen, D. E. \& Green, L. (1991). Recombination in Escherichia coli and the definition of a biological species. Journal of Bacteriology 173, 7257-7268.

FalK, E. S., Bjorvatin, B., Danielsson, D., Kristiansen, B.-E., MeLby, K. \& SORENSEN, B. (1984). Restriction endonuclease fingerprinting of chromosomal DNA of Neisseria gonorrhoeae. Acta Pathologica, Microbiologica et Immunologica Scandinavia B92, 271-278.

Feavers, I. M., Heath, A. B., Bygraves, J. A. \& Maiden, M. C. J. (1992). Role of horizontal genetic exchange in the antigenic variation of the class 1 outer membrane protein of Neisseria meningitidis. Molecular Microbiology 6, 489-495.

Gargallo-Viola, D. (1989). Enzyme polymorphism, prodigiosin production and plasmid fingerprints in clinical and naturally occurring isolates of Serratia marcesens. Journal of Clinical Microbiology 27, 860-868.

Istock, C. A., Duncan, K. E., Ferguson, N. \& Zhou, X. (1992). Sexuality in a natural population of bacteria-Bacillus subtilis challenges the clonal paradigm. Molecular Ecology 1, 95-103.

KNAPP, J. S., TAM, M. R., NowINSKI, R. C., Holmes, K. K. \& SANDSTROM, E. G. (1984). Serological classification of Neisseria gonorrhoeae with use of monoclonal antibodies to gonococcal outer membrane protein I. Journal of Infectious Diseases 150, 44-48.

LeviN, B. R. (1981). Periodic selection, infectious gene exchange and the genetic structure of $E$. coli populations. Genetics 99, 1-23.

MaYnard Smith, J., Dowson, C. G. \& Spratt, B. G. (1991). Localized sex in bacteria. Nature, London 349, 29-31.

Maynard Smith, J., Smith, N. H., O'Rourke, M. \& Spratt, B. G. (1993). How clonal are bacteria? Proceedings of the National Academy of Sciences of the United States of America 90, 4384-4388.

MilkMAN, R. \& BRIDGES, M. M. (1990). Molecular evolution of the Escherichia coli chromosome. III. Clonal frames. Genetics 126, 505-517.

Musser, J. M., Bemis, D. A., Ishikawa, H. \& Selander, R. K. (1987). 
Clonal diversity and host distribution in Bordetella bronchiseptica. Journal of Bacteriology 169, 2793-2803.

Musser, J. M., Kroll, J. S., Moxon, E. R. \& Selander, R. K. (1988). Evolutionary genetics of the encapsulated strains of Haemophilus influenzae. Proceedings of the National Academy of Sciences of the United States of America 85, 7758-7762.

Norusis, M. J. (1986). SPSS/PC+ Advanced statistics for the IBM PC/XT/AT. Chicago, IL: SPSS.

OCHMAN, H. \& SElANDER, R. K. (1984). Evidence for clonal population structure in Escherichia coli. Proceedings of the National Academy of Sciences of the United States of America 81, 198-201.

Piffaretti, J. C., Kressebuch, H., Aeschbachter, M., Bille, J., Bannerman, E., Musser, J. M., Selander, R. K. \& Rocourt, J. (1989). Genetic characterization of clones of the bacterium Listeria monocytogenes causing epidemic disease. Proceedings of the National Academy of Sciences of the United States of America 86, 3818-3822.

PoH, C. L., Ocampo, J. C., SNG, E. H. \& Bygdeman, S. M. (1989). Rapid in situ generation of DNA restriction endonuclease patterns for Neisseria gonorrhoeae. Journal of Clinical Microbiology 27, 2784-2788.

PoH, C. L., KHNG, H. P., LiM, C. K. \& LOH, G. K. (1992). Molecular typing of Neisseria gonorrhoeae by restriction fragment length polymorphisms. Genitourinary Medicine 68, 106-110.

SaRAFian, S. K. \& KNAPP, J. S. (1989). Molecular epidemiology of gonorrhea. Clinical Microbiology Reviews 2, suppl., S49-S55.

SEIFERT, H.S. \& So, M. (1988). Genetic mechanisms of bacterial antigenic variation. Microbiological Reviews 52, 327-336.

Seifert, H. S., AJioka, R. S., Marchal, C., Sparling, P. F. \& So, M. (1988). DNA transformation leads to pilus antigenic variation in Neisseria gonorrhoeae. Nature, London 336, 392-395.

SELANDER, R. K. \& LEVIN, B. R. (1980). Genetic diversity and structure in Escherichia coli populations. Science 210, 545-547.

SELANDER, R. K. \& MUSSER, J. M. (1990). The population genetics of bacterial pathogenesis. In The Molecular Basis of Bacterial Pathogenesis, pp. 11-36. Edited by B. H. Iglewski \& V. L. Clark. Orlando: Academic Press.

Selander, R. K., McKinney, R. M., Whittam, T. S., BibB, W. F., Brenner, D. J., Nolte, F. S. \& Pattison, P. E. (1985). Genetic structure of populations of Legionella pneumophila. Journal of Bacteriology 163, 1021-1037.

Selander, R. K., Caugant, D. A., Ochman, H., Musser, J. M., Gilmour, M. N. \& WhitTAM, T. S. (1986). Methods of multilocus enzyme electrophoresis for bacterial population genetics and systematics. Applied and Environmental Microbiology 51, 873-884.

Selander, R. K., Caugant, D. A. \& Whittam, T. S. (1987). Genetic structure and variation in natural populations of Escherichia coli. In Escherichia coli and Salmonella typhimurium, Cellular and Molecular Biology, vol. 2, pp. 1625-1648. Edited by F. C. Neidhardt, J. L. Ingraham, K. B. Low, B. Magasanik, M. Schaechter \& H. E. Umbarger. Washington, DC: American Society for Microbiology.

Selander, R. K., Beltran, P., Smith, N. H., Helmuth, R., Rubin, F. A., Kopecko, D. J., Ferris, K., Tall, B. D., Cravioto, A. \& MuSSER, J. M. (1990). Evolutionary genetic relationships of clones of Salmonella serovars that cause human typhoid and other enteric fevers. Infection and Immunity 58, 2262-2275.

Souza, V., Ngyen, T. T., Hudson, R. R., Pinero, D. \& Lenski, R. E. (1992). Hierarchial analysis of linkage disequilibrium in Rhizobium populations: evidence for sex? Proceedings of the National Academy of Sciences of the United States of America 89, 8389-8393.

Stern, A., Brown, M., Nickel, P. \& MeYer, T. F. (1986). Opacity genes in Neisseria gonorrhoeae: control of phase and antigenic variation. Cell 47, 61-71.

Stoltzfus, A., Leslie, J. F. \& Milkman, R. (1988). Molecular evolution of the Escherichia coli chromosome. I. Analysis of the structure and natural variation in a previously uncharacterized region between trp and tonB. Genetics 120, 345-358.

Tam, M. R., Buchanan, T. M., Sandstrom, E. G., Holmes, K. K., KNAPP, J. S., SiADAK, A. W. \& NoWINSKI, R. C. (1982). Serological classification of Neisseria gonorrhoeae with monoclonal antibodies. Infection and Immunity 36, 1042-1053.

Wang, J.-F., Caugant, D. A., Li, X., Hu, X., Poolman, J. T., Crowe, B. A. \& AChtman, M. (1992). Clonal and antigenic analysis of serogroup A Neisseria meningitidis with particular reference to epidemiological features of epidemic meningitis in the People's Republic of China. Infection and Immunity 60, 5267-5282.

WeIR, B.S. (1990), Genetic Data Analysis: Methods for Discrete Population Genetic Data. Sunderland, MA: Sinauer Associates.

WhitTAM, T. S. \& WiLson, R. A. (1988). Genetic relationships among pathogenic strains of avian Escherichia coli. Infection and Immunity 56, 2458-2466.

Whittam, T. S., Ochman, H. \& Selander, R. K. (1983a). Multilocus genetic structure in natural populations of Escherichia coli. Proceedings of the National Academy of Sciences of the United States of America 80, 1751-1755.

Whittam, T. S., Ochman, H. \& Selander, R. K. (1983 $b$ ). Geographic components of linkage disequilibrium in natural populations of Escherichia coli. Molecular Biology and Evolution 1, 67-83.

ZhOU, J. \& SPRATT, B. G. (1992). Sequence diversity within the $\arg F$, $f b p$ and $r e c A$ genes of natural isolates of Neisseria meningitidis: interspecies recombination within the $\arg F$ gene. Molecular Microbiology 6, 2135-2146. 